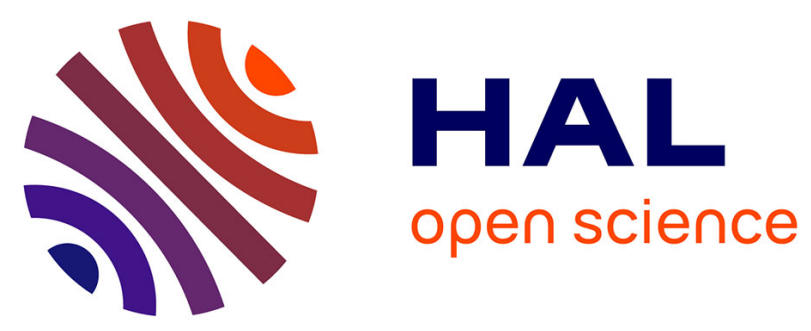

\title{
Combined influences of transgenerational effects, temperature and insecticide on the moth Spodoptera littoralis
}

Manuel Massot, Thibaut Bagni, Annick Maria, Philippe Couzi, Thomas Drozdz, Aude Malbert-Colas, Martine Maïbèche, David Siaussat

\section{To cite this version:}

Manuel Massot, Thibaut Bagni, Annick Maria, Philippe Couzi, Thomas Drozdz, et al.. Combined influences of transgenerational effects, temperature and insecticide on the moth Spodoptera littoralis. Environmental Pollution, 2021, 289, pp.117889. 10.1016/j.envpol.2021.117889 . hal-03335189

\author{
HAL Id: hal-03335189 \\ https://hal.science/hal-03335189
}

Submitted on 6 Sep 2021

HAL is a multi-disciplinary open access archive for the deposit and dissemination of scientific research documents, whether they are published or not. The documents may come from teaching and research institutions in France or abroad, or from public or private research centers.
L'archive ouverte pluridisciplinaire $\mathbf{H A L}$, est destinée au dépôt et à la diffusion de documents scientifiques de niveau recherche, publiés ou non, émanant des établissements d'enseignement et de recherche français ou étrangers, des laboratoires publics ou privés. 


\section{Combined influences of transgenerational effects, temperature and insecticide on the moth Spodoptera littoralis}

Manuel Massot*, Thibaut Bagni, Annick Maria, Philippe Couzi, Thomas Drozdz, Aude Malbert-Colas, Martine Maïbèche, and David Siaussat

Sorbonne Université, CNRS, INRAe, Institut d'Ecologie et des Sciences de l'Environnement de Paris, iEES-Paris, F-75005, Paris, France

*Corresponding author: ORCID: 0000-0002-2762-4417

Phone: +33144272735

E-mail: manuel.massot@sorbonne-universite.fr

E-mail:

Manuel Massot_manuel.massot@sorbonne-universite.fr

Thibaut Bagni_thibaut.bagni@sorbonne-universite.fr

Annick Maria_annick.maria@sorbonne-universite.fr

Philippe Couzi_philippe.couzi@inra.fr

Thomas Drozdz drozdzth@gmail.com

Aude Malbert-Colas aude.malbertcolas@gmail.com

Martine Mä̈bèche martine.maibeche@sorbonne-universite.fr

David Siaussat_david.siaussat@sorbonne-universite.fr 


\begin{abstract}
Climate warming is expected to impact the response of species to insecticides. Recent studies show that this interaction between insecticides and temperature can depend on other factors. Here, we tested for the influence of transgenerational effects on the Insecticide $\mathrm{x}$ Temperature interaction in the crop pest moth Spodoptera littoralis. Specifically, we analysed reaction norms among experimental clutches based on a split-plot design crossing the factors temperature, insecticide and clutch. The study was performed on 2280 larvae reared at four temperatures $\left(23,25,27\right.$ and $\left.29^{\circ} \mathrm{C}\right)$, and their response to the insecticide deltamethrin (three concentrations and a control group) was tested. Temperature had a global influence with effects on larval survival, duration of development, pupal body mass, and significant reaction norms of the clutches for temperature variations of only $2^{\circ} \mathrm{C}$. In addition to the expected effect of deltamethrin on mortality, the insecticide slightly delayed the development of $S$. littoralis, and the effects on mortality and development differed among the clutches. Projection models integrating all the observed responses illustrated the additive effects of deltamethrin and temperature on the population multiplication rate. Variation in the response of the clutches showed that transgenerational effects influenced the impact of insecticide and temperature. Although no evidence indicated that the Insecticide $\mathrm{x}$ Temperature interaction depended on transgenerational effects, the studies on the dependence of the Insecticide $\mathrm{x}$ Temperature interaction on other factors continue to be crucial to confidently predict the combined effects of insecticides and climate warming.
\end{abstract}

Keywords: Pesticide, reaction norm, mortality, development, projection models 


\section{INTRODUCTION}

Climate warming is expected to dramatically increase crop losses due to insect pests (Deutsch et al., 2018). As a consequence, we can anticipate greater insecticide use with the associated costs of environmental pollution, biodiversity reduction and evolution of pest resistance. Furthermore, either ecological risk assessment or pest management will need to address the change in response of species to insecticides with rising temperature (Dinh et al., 2016; Fournier-Level et al., 2016; Hooper et al., 2013; Noyes et al., 2009). Although the focus on this interaction between insecticides and temperature is recent, several kinds of changes are expected. It is known that rising temperatures generally increase the uptake and excretion of insecticides and pollutants (Hooper et al., 2013; Noyes et al., 2009). Most of these responses are likely due to the temperature-induced increase in metabolism in ectotherms such as insects (Hooper et al., 2013). We also expect that the activity of detoxification enzymes responds to temperature as classically observed in other enzymes, with enzyme activity increasing with temperature up to an optimum level and then declining sharply (Angilletta, 2009; Kingsolver, 2009). Another possible effect of temperature is a change in insecticide toxicity (Hooper et al., 2013; Noyes et al., 2009). With climate change, all these responses may impact species resistance to insecticides (Fournier-Level et al., 2016).

However, the predictions concerning the Insecticide $\mathrm{x}$ Temperature interaction could be refined. In fact, this interaction has been recently shown to depend on other factors (Dinh et al., 2016; Tran et al., 2018; Whiten \& Peterson, 2016). In the vector mosquito Aedes aegypti (Diptera, Culicidae, Linnaeus 1762), Whiten \& Peterson (2016) found that the interaction between temperature and permethrin insecticide depends on the temperature itself. The sign of the relationship between temperature and permethrin toxicity reverses along a thermal gradient. In the damselfly Coenagrion puella (Odonata, Coenagrionidae, Linnaeus 1758), Dinh et al. (2016) found that the mortality caused by the insecticide chlorpyrifos increases 
dramatically in larvae previously exposed to a heat wave and starvation. In the mosquito Culex pipiens (Diptera, Culicidae, Linnaeus 1758), the same research team showed that the interactive effect of warming on mortality caused by chlorpyrifos disappeared in the offspring of parents previously exposed to both warming and insecticide (Tran et al., 2018). In this context, we aimed to test for transgenerational effects on the Insecticide $\mathrm{x}$ Temperature interaction in another insect model, the crop pest moth Spodoptera littoralis (Lepidoptera, Noctuidae, Boisduval 1833). It is especially justified to investigate transgenerational effects on the Insecticide $\mathrm{x}$ Temperature interaction in S. littoralis because a maternal effect on sensitivity to an insecticide was recently detected in this species. The mortality caused by chlorpyrifos is indeed higher in larvae of larger mothers (Bagni et al., 2020). Such transgenerational dependence is expected to be common because offspring quality often depends on parental traits (Marshall et al., 2010; Moore et al., 2019; Mousseau et al., 2009). Here we tested transgenerational effects on the Insecticide $\mathrm{x}$ Temperature interaction by analysing reaction norms among experimental clutches. Specifically, we tested clutch effects, i.e., variation in the response of families based on a survey of full siblings. In another moth species, Rothschildia lebeau (Lepidoptera, Saturniinae, Guérin-Meneville 1868), variation among families explains a large part of the variation in larval survival and growth rates, 31 and $45 \%$ of the total variation observed, respectively (Agosta, 2008). Moreover, Kingsolver et al. (2004) provides an illustrative example of thermal reaction norm in the butterfly Pieris rapae (Lepidoptera, Pieridae, Linnaeus 1758), with a variation in the response of families for larvae reared under different temperatures.

We performed the study with the insecticide deltamethrin, which is one of the most used synthetic pyrethroids worldwide (WHO, 1989). Pyrethroids display high efficacy on targeted insects and decreased toxicity on non-targeted vertebrates (Bradbury \& Coats, 1989; Goulding et al., 2013). This molecule induces toxic responses in the central and peripheral 
nervous systems of insects by interacting with voltage-gated sodium channels (Haug \& Hoffman, 1990). Pyrethroids are classified into two types. Type 1 and some type 2 pyrethroids are less toxic at elevated temperatures, but some type 2 pyrethroids are more toxic at elevated temperatures (Hooper et al., 2013). Deltamethrin is a type 2 pyrethroid, but a previous study on larvae of $S$. littoralis showed that it is less toxic at an elevated temperature (Riskallah, 1984). Larvae are the main target of insecticides in S. littoralis, and deltamethrin has the highest toxicity early in the development of $S$. littoralis, especially at the $4^{\text {th }}$ instar studied by Riskallah (Malbert-Colas et al., 2020). The study of Riskallah (1984) tested the toxicity of deltamethrin at two temperatures, 20 and $35^{\circ} \mathrm{C}$. However, it has been recommended to investigate smaller variations in temperature to capture the nonlinear influence of temperature on most biological processes (Mordecai et al., 2019; Sinclair et al., 2016). Furthermore, searching the effects of smaller temperature variations is consistent with the expected climate warming. Therefore, we aimed to test the responses between four close temperatures: $23,25,27$ and $29^{\circ} \mathrm{C}$. Experimental temperatures were applied during all development stages, i.e., from eggs to adult emergence. We chose these temperatures near the thermal optimum of $S$. littoralis because species responses to temperature are more accurately measured near their thermal optima (Johnson et al., 2015). In a preliminary study to determine the thermal optimum of $S$. littoralis, we found the highest population multiplication rate at temperatures of 27 and $29^{\circ} \mathrm{C}$ (Fig. S1). Moreover, a temperature of $30^{\circ} \mathrm{C}$ is known to induce high pupal mortality and inhibit reproduction in both sexes (Sidibé \& Laugé, 1977).

To test the Insecticide x Temperature interaction, we used a split-plot design crossing four temperatures with four deltamethrin treatments. The moth traits investigated were larval survival, pupal survival, duration of development, and pupal body mass. To synthesise the effect of temperature on multiple traits as advised (Bruijning et al., 2018; Mordecai et al., 2019), we performed population projection models. The global response was assessed based 
on estimates of the asymptotic growth rate obtained from matrix modelling of the $S$. littoralis life cycle. This approach allowed us to evaluate the relative importance of the response of the different moth traits tested. With regard to Riskallah's study (1984) that found a decreased deleterious effect of deltamethrin on larval survival between 20 and $35^{\circ} \mathrm{C}$, we will determine (i) if the decrease in the deleterious effect of deltamethrin is also observed between less extreme temperatures, (ii) if effects on moth traits other than larval survival mask this response, and (iii) crucially, if this Insecticide x Temperature interaction is sensitive to transgenerational effects.

\section{MATERIALS AND METHODS}

\section{Study system}

We studied the cotton leafworm Spodoptera littoralis, a major pest insect. The larvae of this African and Mediterranean moth damage 87 plant species of economic importance such as cotton, maize, and tomato (CABI, 2020), making this species one of the most destructive agricultural pests. S. littoralis can complete two to seven generations per year (Khafagi et al., 2016). Larval development is complete with six or seven instars (depending on environmental conditions) (Baker \& Miller, 1974), and the last two larval instars induce approximately 90 to $95 \%$ of plant defoliation (Khafagi et al., 2016). A laboratory strain of S. littoralis was used, with larvae reared on a semiartificial diet (Hinks \& Byers, 1976), at $23^{\circ} \mathrm{C}, 60-70 \%$ relative humidity, and a 16:8 light/dark cycle until adult emergence. Individuals were sexed as pupae.

To choose experimental temperatures, we performed a preliminary study in spring 2017 with four temperatures $\left(23,25,27\right.$ and $\left.29^{\circ} \mathrm{C}\right)$ that were applied from eggs to adult emergence. As in our main experiment, the relative humidity was $60-70 \%$, and the light/dark cycle was 16:8. We measured the early larval survival rate (between the $1^{\text {st }}$ and $4^{\text {th }}$ larval instars), late larval 
survival rate (between the $4^{\text {th }}$ larval instar and pupation), pupal survival rate, and developmental times (duration of incubation, between the $1^{\text {st }}$ and $4^{\text {th }}$ larval instars, between the $4^{\text {th }}$ larval instar and pupation, and between pupation and adult emergence). Based on these data, we estimated the multiplication rate of our S. littoralis strain for each developmental temperature and found optimal developmental temperatures at 27 and $29^{\circ} \mathrm{C}$ (Fig. S1).

\section{Experiments}

Experimental clutches were obtained from mating pairs of 1 female and 1 male, with two- or three-day-old adults. Mating occurred in round plastic boxes $(10 \mathrm{~cm}$ in diameter) with sugar water $(20 \mathrm{~g} / \mathrm{L})$ as a food source and a strip of filter paper as a laying medium. We collected clutches only 24 hours after mating, i.e., at the peak of egg laying (Kehat \& Gordon, 1975) to limit variation in offspring quality. Clutches were collected at 14 days of 5 weeks, from $5^{\text {th }}$ February to $13^{\text {th }}$ Marsh 2018.

Figure 1 shows the split-plot design we used to test the response of clutches to temperature and deltamethrin insecticide, i.e., the reaction norms of clutches to the two experimental factors. To carry out this experiment, most clutches collected were immediately divided into two parts to rear them under different temperatures (clutches reared at 23 or $25^{\circ} \mathrm{C}$, and clutches reared at 27 or $29^{\circ} \mathrm{C}$ ). Temperature was controlled independently of relative humidity (fixed to 70\%) with environmental test chambers (Panasonic MLR-352H). When larvae were at the $4^{\text {th }}$ instar, each of the half-clutches was divided into four groups where the deltamethrin treatments were applied. We treated 15 larvae in each deltamethrin group of half-clutches (Fig. 1). The test solutions were prepared from an initial solution of 5,052 $\mathrm{mg}$ of deltamethrin (45423, Sigma Pestanal, France) dissolved in $1 \mathrm{~mL}$ of absolute ethanol. Serial dilutions with ethanol were then made from this overconcentrated solution. Our final 
concentrations of the treatments were obtained by diluting these solutions with pure hexane. Hexane was used as a solvent because deltamethrin is an apolar insecticide with a low solubility in polar solvents such as water or ethanol. The high volatility of hexane is also an advantage for topical application since the solvent quickly dissipates. Our treatments were compared to a control group treated with a solution of $15 \%$ ethanol and $85 \%$ hexane. This ratio was chosen because it corresponded to the highest quantity of ethanol in our treatment solutions. The solution of the control group had no or a very low toxicity as shown in previous studies of S. littoralis (Lalouette et al., 2016; Malbert-Colas et al., 2020). Topical applications of $0.5 \mu \mathrm{L}$ of the test solutions to the head of larvae were performed using a microapplicator (Hamilton $25 \mu \mathrm{L}$ syringe and Hamilton dispenser). The concentrations of deltamethrin tested were $0.076,0.76$ and $5.05 \mathrm{mg} / \mathrm{L}$ as in previous studies (Lalouette et al., 2016; Malbert-Colas et al., 2020), and these concentrations corresponded to doses of 0.038, 0.380 and $2.525 \mathrm{ng}$ of deltamethrin per larva, respectively. Under a developmental temperature of $23^{\circ} \mathrm{C}$, our highest concentration of deltamethrin $(5.05 \mathrm{mg} / \mathrm{L})$ applied at the beginning of the $4^{\text {th }}$ larval instar led to the mortality of all larvae (Malbert-Colas et al., 2020). Our intermediate concentration of deltamethrin $(0.76 \mathrm{mg} / \mathrm{L})$ led to either $95 \%$ mortality in the main experimental series or $31 \%$ mortality in a complementary experiment (Malbert-Colas et al., 2020). This result showed that the limit between high and low mortality effects at the $4^{\text {th }}$ larval instar was very close to our intermediate deltamethrin concentration. Our lowest concentration of deltamethrin $(0.076 \mathrm{mg} / \mathrm{L})$ did not induce significant mortality (mortality rate of $15 \%$ that did not differ from a control group). In addition to our intermediate concentration, we chose to retain the lowest and highest deltamethrin concentrations in our study because their impact might change with temperature.

After the insecticide treatment, each group of 15 larvae was reared until pupation in experimental plastic boxes of $225 \times 145 \times 72 \mathrm{~mm}$, with a net on the top of boxes. Overall, the 
experiment was performed on 2880 larvae reared in 192 experimental boxes (one per combination crossing the factors clutch, temperature and deltamethrin treatment). Experimental boxes were checked daily to monitor larvae and pupae until adult emergence. This survey allowed us to estimate developmental time, larval survival, and pupal survival. Developmental time was defined as the duration between the deltamethrin treatment (at the $4^{\text {th }}$ larval instar) and adult emergence. We measured larval survival between the deltamethrin treatment and pupation. All larvae that survived until pupation were sexed to differentiate pupal survival of males and females. For each experimental box, we also weighed pupae, two males and two females, to estimate pupal body mass.

\section{Statistical analyses}

Larval survival, pupal survival, developmental time and pupal body mass were analysed in two steps. First, we tested the effects of developmental temperature, deltamethrin, and their interaction. Second, we investigated variation in the response of clutches to temperature and deltamethrin (reaction norms). Our experimental design (Fig. 1) allowed us to test reaction norms for clutches that were divided and reared under two different temperatures ( 23 and $25^{\circ} \mathrm{C}$ or 27 and $29^{\circ} \mathrm{C}$ ). Thus, these tests were performed separately for clutches reared at 23 and $25^{\circ} \mathrm{C}$ and for clutches reared at 27 and $29^{\circ} \mathrm{C}$. We modelled the clutch factor with our clutch identification numbers and alternatively with the date of collection of clutches (day or week). Indeed, temporal fluctuations were observed in our rearing (Bagni et al., 2020) and might describe more parsimonious variation among clutches. We compared statistical models with no clutch variation, total variation among clutches, and variation on the date of the collection of clutches. The comparison was based on the AICc of models, i.e., Akaike Information Criterion corrected for small sample size (White \& Burnham, 1999). When a variation among clutches was detected (temporal or total variation), we reported the results on 
the interactions between the selected clutch factor and experimental factors (interactions Temperature x Clutch, Deltamethrin x Clutch, and Temperature x Deltamethrin x Clutch). These interactions tested the variation in the response of clutches to temperature and deltamethrin.

We analysed our binomial variables (larval survival and pupal survival) using logistic models. For continuous dependent variables (developmental time and pupal body mass), we used ANOVA in our first analysis limited to temperature and deltamethrin effects. The statistical models used to investigate reaction norms were generalized linear models that included random factors (clutch or date factors) in mixed-effects linear models. We checked the residuals of models for normality and homoscedasticity. Normality and homoscedasticity were not satisfied for developmental time (even log transformed), and we had to use logistic models for this variable. Developmental time was discretized into a binomial variable. We discretized developmental time with regard to the median values of each experimental temperature to retain variation to test the Temperature x Deltamethrin interaction. Indeed, developmental times overlapped very little between experimental temperatures: the $99 \%$ confidence interval of the developmental time between the $4^{\text {th }}$ larval instar and adult emergence was $28.6-29.1$ days at $23^{\circ} \mathrm{C}(n=313), 23.4-23.9$ days at $25^{\circ} \mathrm{C}(n=345), 19.6$ 20.0 days at $27^{\circ} \mathrm{C}(n=399)$, and $18.2-18.5$ days at $29^{\circ} \mathrm{C}(n=398)$. All analyses were performed with JMP software (JMP Pro 15, SAS Institute Inc., Cary, NC), and all models were simplified by backward stepwise removal of terms with $P>0.10$.

\section{Projection matrix models}

To evaluate the relative importance of the response of the different moth traits tested, we built matrix models to estimate the multiplication rate at the population level (Caswell, 2001). 
Specifically, we used the asymptotic growth rate (i.e., intrinsic rate of increase) as a proxy for population dynamics (Caswell, 2001; Metcalf \& Pavard, 2007). Our models were based solely on females as is usual for this kind of demographic modelling. This approach assumes that male abundance is high enough to ensure reproduction by most females (Bessa-Gomes et al., 2010). This assumption was relevant to our study where $55 \%$ of pupae were males. We modelled the life cycle of $S$. littoralis based on an age-structured matrix where each age class was 1 day, and we calculated the population growth rate as the dominant eigenvalue of the matrix. We parameterised this daily matrix model with the vital parameters estimated in the

present study (survival between the $4^{\text {th }}$ larval instar and pupation, pupal survival, duration between the $4^{\text {th }}$ larval instar and pupation, duration of pupal period, and sex-ratio). We used estimates from our preliminary study in spring 2017 for duration of incubation period and for survival and duration between the $1^{\text {st }}$ and $4^{\text {th }}$ larval instars. Adult female survival until laying, laying success after mating, number of eggs laid, and hatching success were obtained from another study (Malbert-Colas et al., 2020). All the values used in the models are given in Table S1. Our modelling was performed with the computer program ULM ('Unified Life Models') (Ferrière et al., 1996; Legendre \& Clobert, 1995). ULM can be downloaded from http://www.biologie.ens.fr/ legendre/ulm/ulm.html. This program enabled us to estimate the growth-rate sensitivity and elasticity (i.e., relative sensitivity) to changes in the different vital parameters tested (Caswell, 2001; Ferrière et al., 1996).

\section{RESULTS}

\section{Effects of temperature and deltamethrin}

We first tested the effects of developmental temperature and deltamethrin on larval survival between the $4^{\text {th }}$ larval instar and pupation, i.e., on the period beginning at the deltamethrin 
treatment. Larval survival rates differed between deltamethrin treatments $\left(X^{2}{ }_{3}=1065.8, P<\right.$ $0.001)$ and temperatures $\left(X^{2}{ }_{3}=15.3, P=0.002\right)$, but no interaction was detected between deltamethrin and temperature $\left(X^{2}{ }_{9}=6.4, P=0.69\right)$. Fig. 2 shows a dramatic decrease in larval survival with the highest deltamethrin concentration of $5.05 \mathrm{mg} / \mathrm{L}\left(X^{2}{ }_{1}=821.5, P<0.001\right.$ for the test versus the control group) and decreased larval survival with the intermediate concentration of $0.76 \mathrm{mg} / \mathrm{L}\left(X^{2}{ }_{1}=43.4, P<0.001\right)$. Larval survival rates did not differ between the lowest deltamethrin concentration of $0.076 \mathrm{mg} / \mathrm{L}$ and the control group $\left(X^{2}{ }_{1}=\right.$ $0.2, P=0.62$ ). The temperature effect on larval survival was not significant in the control group $\left(X^{2}{ }_{3}=0.7, P=0.87\right)$ or in the group with the highest deltamethrin concentration $\left(X^{2}{ }_{3}=\right.$ 3.0, $P=0.39$ ). The temperature effect was significant in the deltamethrin groups with the intermediate concentration $\left(X^{2}{ }_{3}=10.1, P=0.018\right)$ and the lowest concentration $\left(X^{2}{ }_{3}=7.9, P\right.$ $=0.049$ ). Larval survival slightly increased at the warmest temperatures of 27 and $29^{\circ} \mathrm{C}$ (Fig. 2).

The dramatic decrease in larval survival with the highest concentration of deltamethrin (Fig. 2) led to very small sample sizes (see Table S2d). Consequently, we were unable to include this deltamethrin treatment in the analyses on pupal survival, developmental time until adult emergence, and pupal body mass. Female pupal survival did not respond significantly to deltamethrin $\left(X^{2}{ }_{2}=1.2, P=0.56\right)$ and temperature $\left(X^{2}{ }_{3}=1.6, P=0.67\right)$, or to their interaction $\left(X^{2}{ }_{6}=3.4, P=0.76\right)$. Similarly, male pupal survival rates did not depend on deltamethrin $\left(X^{2} 2\right.$ $=2.0, P=0.37)$ or temperature $\left(X^{2}{ }_{3}=3.6, P=0.31\right)$, with no interaction between the two factors $\left(X^{2}{ }_{6}=8.4, P=0.21\right)$. Overall, the pupal survival rates of females and males were constantly high (Fig. S2).

Figure 3 shows a dramatic shortening of development at the warmest temperatures in females and males. As previously detailed (see Materials and Methods), the 99\% confidence intervals 
of the developmental time did not overlap between the four experimental temperatures. In addition, the developmental time of females differed significantly between deltamethrin treatments $\left(X^{2}{ }_{2}=20.1, P<0.001\right)$, with no interaction between deltamethrin and temperature $\left(X^{2}{ }_{6}=7.6, P=0.27\right)$. Females had a slight lengthening of their development with the deltamethrin concentration treatment of $0.76 \mathrm{mg} / \mathrm{L}$ compared to the control group $\left(X^{2}{ }_{1}=9.3\right.$, $P=0.002$; Fig. 3A). The lowest deltamethrin concentration of $0.076 \mathrm{mg} / \mathrm{L} \mathrm{did} \mathrm{not}$ significantly affect female developmental time $\left(X^{2}{ }_{1}=2.0, P=0.15\right)$. The developmental time of males also differed between deltamethrin treatments but through a significant interaction between deltamethrin and temperature $\left(X^{2}{ }_{6}=24.0, P<0.001\right)$. Males had a lengthening of their development with the deltamethrin concentration treatment of $0.76 \mathrm{mg} / \mathrm{L}$ compared to the control group at temperatures of $23^{\circ} \mathrm{C}\left(X^{2}{ }_{1}=7.5, P=0.007\right), 25^{\circ} \mathrm{C}\left(X^{2}{ }_{1}=4.7, P=0.031\right)$ and $27^{\circ} \mathrm{C}\left(X^{2}{ }_{1}=7.0, P=0.008\right)$, with no effect detected at $29^{\circ} \mathrm{C}\left(X^{2}{ }_{1}<0.1, P=0.92\right)$ (Fig. 3B). This lengthening of male development was only found at $25^{\circ} \mathrm{C}$ with the lowest deltamethrin concentration of $0.076 \mathrm{mg} / \mathrm{L}\left(X^{2}{ }_{1}=13.4, P<0.001 ; P>0.23\right.$ for other temperatures).

Pupal body mass decreased as the developmental temperature increased (Fig. 3C and D). The pupal body mass of females was influenced by temperature $\left(F_{3,270}=32.7, P<0.001\right)$ but not by deltamethrin $\left(F_{2,268}=0.8, P=0.44\right)$ or the interaction between deltamethrin and temperature $\left(F_{6,262}=0.9, P=0.50\right)$. The results were the same in males with an effect from temperature $\left(F_{3,279}=16.4, P<0.001\right)$, no significant effect from deltamethrin $\left(F_{2,277}=1.7, P\right.$ $=0.18)$, and no interaction between deltamethrin and temperature $\left(F_{6,271}=0.3, P=0.94\right)$.

\section{Reaction norms}

Our split-plot experimental design (Fig. 1) allowed us to investigate variation among clutches and variation in the response of clutches to temperature and deltamethrin (reaction norms). 
Variation among clutches was tested for both clutches reared at 23 and $25^{\circ} \mathrm{C}$, and clutches reared at 27 and $29^{\circ} \mathrm{C}$. We focused the analyses on our intermediate deltamethrin concentration treatment $(0.76 \mathrm{mg} / \mathrm{L})$ compared to the control treatment. Indeed, previous analyses have shown very limited effects of the lowest concentration, and the dramatic larval mortality induced by the highest concentration (Fig. 2) prevented from performing tests on variation among clutches.

First, we compared the statistical models with no clutch variation, total variation among clutches, and variation in the day or week of the collection of the clutches (see Table S3 for the comparison of models). We did not detect variation among clutches in terms of pupal survival and pupal body mass, in either males or females. However, larval survival and developmental time varied among clutches. Larval survival under rearing temperatures of 23 and $25^{\circ} \mathrm{C}$ appeared to be dependent on the day of collection of the experimental clutches. The day of collection of the clutches also fit the data better than other clutch variations for developmental times of males at 23 and $25^{\circ} \mathrm{C}$ and of females at 27 and $29^{\circ} \mathrm{C}$. The daily variation in the developmental times of females at 23 and $25^{\circ} \mathrm{C}$ (the second best-fit model) was modelled even more parsimoniously with the week of collection of the clutches. Last, the total clutch variation fit the data of males at 27 and $29^{\circ} \mathrm{C}$ better than clutch variation limited to temporal fluctuations.

When a variation among clutches was detected (modelled as a variation among clutches, days or weeks), we focused on the variation in the response of the clutches to temperature and deltamethrin treatments. Significant reaction norms were found in most of these tests (Table 1). We detected variation in the response of the clutches to temperature for larval survival, developmental time of females, and developmental time of males. Significant reaction norms to temperature for the developmental time of both sexes were observed at 23 and $25^{\circ} \mathrm{C}$, as 
well as at 27 and $29^{\circ} \mathrm{C}$. Variation in the response of the clutches to deltamethrin was detected for larval survival and male developmental time. It is to note that the variation in the response of clutches to the combined effects of temperature and deltamethrin (interactions Temperature x Deltamethrin x Clutch factors) were not significant, even though the interaction Temperature $\mathrm{x}$ Deltamethrin $\mathrm{x}$ Week of clutch collection was close to be significant for female developmental time at 23 and $25^{\circ} \mathrm{C}\left(X^{2}{ }_{3}=7.7, P=0.052\right)$.

\section{Projection models}

We performed simulations with demographic models to integrate the different observed responses among the studied parameters and evaluate their relative importance. We modelled the scenarios crossing the combination of experimental temperatures and deltamethrin treatments (values used to fix the parameters are given in Table S1). Fig. 4 shows the multiplication rate of the 16 simulated scenarios. All the scenarios resulted in a population increase (multiplication rates $>1$ ), even with the worst scenario combining very low larval survival with the highest deltamethrin concentration of $5.05 \mathrm{mg} / \mathrm{L}$ (Fig. 2) and slow development at $23^{\circ} \mathrm{C}$ (Fig. 3). However, the multiplication rates differed greatly among the scenarios from this worst scenario to the most favourable one. The latter was for the control group reared at the highest temperature of $29^{\circ} \mathrm{C}$ (Fig. 4). Thus, we confirmed our preliminary observations (Fig. S1). Moreover, as expected, deltamethrin decreased the multiplication rates, especially at the highest concentration (Fig. 4). However, we did not find evidence that the effect of deltamethrin was influenced by temperature, with similar decreases in the multiplication rate between the four experimental temperatures.

We performed an elasticity analysis to estimate the sensitivity of the multiplication rate to the proportional changes in the vital rates. Based on these relative sensitivities, the elasticity analysis allowed a comparison of the impact of the variation in the different types of 
parameters (Caswell, 2001; Ferrière et al., 1996). The analysis showed low sensitivities for all the parameters related to reproduction (Fig. 5). The highest sensitivities of the multiplication rate were revealed for pupal survival, late larval survival (after the $4^{\text {th }}$ larval instar), early larval survival (before the $4^{\text {th }}$ larval instar), and developmental time. In this study, we were able to test the impact of temperature and deltamethrin on three of these four most influential parameters. The frailty of larvae to handling before the $4^{\text {th }}$ instar prevented the test on early larval survival.

\section{DISCUSSION}

Temperature and deltamethrin induced additive effects on the population multiplication rate (Fig. 4). The temperature effect was mainly a change in developmental time (Fig. 3), and the deltamethrin effect was mainly an impact on larval mortality (Fig. 2). Developmental time and larval survival were identified as two influential parameters on the population multiplication rate in S. littoralis (Fig. 5). For these key parameters, we also revealed significant reaction norms of the clutches for variations of only $2^{\circ} \mathrm{C}$, as well as for the response to deltamethrin (Table 1). However, the clutches did not seem to respond differently to the Deltamethrin x Temperature interaction. We found an interaction close to significance only between deltamethrin, temperature and the week of clutch collection for female developmental time. More generally, no clear evidence was obtained for the Deltamethrin x Temperature interaction. A significant Deltamethrin x Temperature interaction was found for the male developmental time, but only small differences caused this interaction. Similarly, we showed only a slight effect in accordance with the result of Riskallah's study (1984), with a significantly decreased toxicity on larval survival between low and high temperatures for the intermediate and lowest concentrations of deltamethrin.

\section{Impact of rising temperature}


Temperature influences almost all performances in ectotherms such as insects (Angilletta, 2009; Dillon et al., 2009). Accordingly, we showed the influence of temperature on developmental time, larval survival, pupal body mass, multiplication rate, and variation in the reaction norms of clutches. Rising temperatures usually increase the metabolic rate in insects (Deutsch et al., 2018) and consequently accelerate their development as we found (Fig. 3). This is a major concern in terms of the impact of climate warming on pest species because faster development can increase the number of generations per year in species with multiple annual generations (Altermatt, 2010). This is the case in S. littoralis which can complete two to seven generations per year (Khafagi et al., 2016).

A temperature of $30^{\circ} \mathrm{C}$ inhibits reproduction and induces high pupal mortality in S. littoralis (Sidibé \& Laugé, 1977). We revealed here that the thermal optimum was $29^{\circ} \mathrm{C}$, with the highest multiplication rate in the control group without deltamethrin (Fig. 4) and with the same observation in our preliminary study (Fig. S1). This result means that the upper thermal limit is very close to the thermal optimum in S. littoralis, as observed in other tropical insect species (Deutsch et al., 2008). The thermal optimum at $29^{\circ} \mathrm{C}$ is mainly due to the dramatic shortening of developmental time at the warmest temperatures (Fig. 3). Indeed, the shortening of the developmental time between 23 and $29^{\circ} \mathrm{C}$ was $36.1 \%$ in females and $36.7 \%$ in males. This faster development was detrimental to pupal body mass, which decreased as temperature increased (Fig. 3), as predicted by the temperature-size rule (Atkinson et al., 1996).

It is recommended to study the effects of temperature on developmental plasticity with multiple parameters because the effects often differ between parameters (Mordecai et al., 2019; Sinclair et al., 2016). Here we tested the effects on four parameters, three of them which were the most influential on the multiplication rate of S. littoralis: larval survival between the $4^{\text {th }}$ instar and pupation, pupal survival and developmental time (Fig. 5). We did not test reproductive parameters that minimally impact the multiplication rate (Fig. 5) for 
temperatures below $30^{\circ} \mathrm{C}$ where reproduction is possible (Sidibé \& Laugé, 1977). Regardless of the experimental temperatures and insecticide treatments, the estimated multiplication rates were higher than 1 (Fig. 4). These high multiplication rates can be mainly explained by the high reproductive capacity of this pest species (Malbert-Colas et al., 2020). Indeed, the multiplication rate was higher than 1 even with the dramatic mortality induced by the highest deltamethrin concentration (Fig. 2).

\section{Effects of deltamethrin insecticide}

The highest concentration of deltamethrin $(5.05 \mathrm{mg} / \mathrm{L})$ induced the mortality of most larvae under the four temperatures tested (Fig. 2), as observed in a previous study at a temperature of $23^{\circ} \mathrm{C}$ (Malbert-Colas et al., 2020). The intermediate concentration of deltamethrin (0.76 $\mathrm{mg} / \mathrm{L}$ ) induced an intermediate level of larval mortality that was between two previous estimates (31 and $95 \%$ ) at $23^{\circ} \mathrm{C}$ (Malbert-Colas et al., 2020). Moreover, this concentration slightly delayed the development of males and females. Pupal survival and body mass were not sensitive to this deltamethrin concentration in either sexes. Interestingly, we found that the response to deltamethrin differed among the clutches in terms of larval survival and developmental time (Table 1). This result illustrates a variation in the sensitivity of clutches to this insecticide. We previously detected another transgenerational effect in S. littoralis on sensitivity to the insecticide chlorpyrifos, with a relationship between maternal body mass and offspring sensitivity to chlorpyrifos (Bagni et al., 2020).

Riskallah (1984) showed a Temperature x Deltamethrin interaction in S. littoralis for larval survival, with a decrease in deltamethrin toxicity between 20 and $35^{\circ} \mathrm{C}$. The toxicity of our intermediate concentration of deltamethrin was also lower at 27 and $29^{\circ} \mathrm{C}$ than at 23 and $25^{\circ} \mathrm{C}$. However, the decrease in deltamethrin toxicity was small in our study. A first explanation of this weak Temperature $\mathrm{x}$ Deltamethrin interaction might be the smaller 
temperature variation we tested. An alternative explanation might involve the sequence of the deltamethrin and temperature treatments. Riskallah applied deltamethrin to larvae at the $4^{\text {th }}$ instar and then exposed larvae to experimental temperatures of 20 and $35^{\circ} \mathrm{C}$. Experimental temperatures were applied from the egg stage in our study, and consequently the deltamethrin treatment of larvae (also at the $4^{\text {th }}$ instar) was applied later. Effects can differ depending on the sequence of toxicant and temperature treatments as highlighted by the literature on 'toxicant-induced climate susceptibility' and 'climate-induced toxicant sensitivity' (Moe et al., 2013; Noyes \& Lema, 2015).

\section{Variation among clutches}

The study showed that variation among clutches is a key factor in S. littoralis, as found in another moth (Agosta, 2008). Variation among the clutches was detected for larval survival and developmental time, two key parameters in S. littoralis (Fig. 5). Analyses of the reaction norms also showed that the clutches responded differently to temperature and deltamethrin. Again, this was detected for larval survival and developmental time (Table 1). Differences of $2^{\circ} \mathrm{C}$ (between 23 and $25^{\circ} \mathrm{C}$ or between 27 and $29^{\circ} \mathrm{C}$ ) were sufficient to induce variation in the response of the clutches to temperature. This result suggests a variation in the thermal optimum of the clutches because we studied temperatures close to the thermal optimum of $S$. littoralis. Variation in the response of clutches to deltamethrin indicates variation in their sensitivity to this insecticide.

Variation among clutches observed in our study is not surprising because such family effects with small amount of variation among full siblings are widely expected (Marshall et al., 2010; Moore et al., 2019; Mousseau et al., 2009). They can be genetic or nongenetic effects. Genetic effects are not expected in our laboratory strain and not consistent with rapid temporal fluctuations observed in our rearing (Bagni et al., 2020). Nongenetic transgenerational effects 
better reflect variation among clutches observed in our studies. These effects involve embryo modifications (energetic provisioning, hormones, toxins, offspring size, etc.) or epigenetic alterations (DNA methylation and histone modification) (Bernardo, 1996b, 1996a; Latzel, 2015). Offspring quality is often influenced by maternal traits and maternal environmental history (Marshall et al., 2010; Moore et al., 2019; Mousseau et al., 2009), notably in insects (Mousseau \& Dingle, 1991; Mousseau \& Fox, 1998). In S. littoralis, we did not have data to test epigenetic alterations (Latzel, 2015; Oppold et al., 2015), but we previously found that maternal body mass influences larval body mass and larval survival (Bagni et al., 2020). We also showed that the mortality caused by the insecticide chlorpyrifos is higher in larvae of larger mothers, providing evidence for transgenerational effects on the sensitivity of $S$. littoralis to insecticides (Bagni et al., 2020).

\section{Conclusion}

Reaction norm analyses are uncommon in ecotoxicology although the parental lineage of experimental individuals can often be known. The benefit of such analyses is illustrated here by the observed reaction norms of clutches to deltamethrin and temperature. Indeed, they revealed that transgenerational effects influence the impact of insecticide and temperature in S. littoralis. We are currently working on a similar study with the organophosphorus insecticide chlorpyrifos because results might differ with an insecticide like chlorpyrifos that is expected to be more toxic at an elevated temperature (Hooper et al., 2013). Although no evidence indicated that transgenerational effects influence the Insecticide $\mathrm{x}$ Temperature interaction in our study with deltamethrin, we encourage ecotoxicologists to continue to investigate the sensitivity of the Insecticide $\mathrm{x}$ Temperature interaction to other factors. In particular, determining the sensitivity of this interaction might be important to assess the future ecological impact of insecticides on non-target species (Dinh et al., 2016; Müller, 
2018). It remains crucial to study interactions between different stressors related to anthropogenic environmental effects (Orr et al., 2020) such as climate warming and pesticide use.

\section{ACKNOWLEDGEMENTS}

This research was supported by the Région Ile-de-France (DIM R2DS 2014) to purchase environmental test chambers and by the CNRS (PEPS FaiDoRA). 


\section{REFERENCES}

Agosta, S. J. (2008). Fitness consequences of host use in the field: Temporal variation in performance and a life history tradeoff in the moth Rothschildia lebeau (Saturniidae). Oecologia, 157(1), 69-82. https://doi.org/10.1007/s00442-008-1059-1

Altermatt, F. (2010). Climatic warming increases voltinism in European butterflies and moths. Proceedings of the Royal Society B-Biological Sciences, 277(1685), 12811287.

Angilletta, M. J. (2009). Thermal adaptation: A theoretical and empirical synthesis. Oxford Univ. Press.

Atkinson, D., Johnston, I., \& Bennett, A. F. (1996). Ectotherm life-history responses to developmental temperature. Anim. Temp. Phenotypic Evol. Adapt, 183-204. https://doi.org/10.1017/CBO9780511721854.009

Bagni, T., Siaussat, D., Maria, A., Couzi, P., Maïbèche, M., \& Massot, M. (2020). A maternal effect influences sensitivity to chlorpyrifos pesticide in the pest moth Spodoptera littoralis. Ecotoxicology and Environmental Safety, 204, 111052. https://doi.org/10.1016/j.ecoenv.2020.111052

Baker, C., \& Miller, G. (1974). Some effects of temperature and larval food on the development of Spodoptera littoralis (Boisd.) (Lep.,Noctuidae). Bulletin of Entomological Research, 63, 495-511.

Bernardo, J. (1996a). Maternal effects in animal ecology. American Zoologist, 36(2), 83-105. https://doi.org/10.1093/icb/36.2.83

Bernardo, J. (1996b). The particular maternal effect of propagule size, especially egg size: Patterns, models, quality of evidence and interpretations. American Zoologist, 36(2), 216-236. https://doi.org/10.1093/icb/36.2.216 
Bessa-Gomes, C., Legendre, S., \& Clobert, J. (2010). Discrete two-sex models of population dynamics: On modelling the mating function. Acta Oecologica, 36(5), 439-445. https://doi.org/10.1016/j.actao.2010.02.010

Bradbury, S. P., \& Coats, J. R. (1989). Comparative toxicology of the pyrethroid insecticides. In G. W. Ware (Ed.), Reviews of Environmental Contamination and Toxicology (pp. 133-177). Springer New York. https://doi.org/10.1007/978-1-4613-8850-0_4

Bruijning, M., Berge, A. C. M., \& Jongejans, E. (2018). Population-level responses to temperature, density and clonal differences in Daphnia magna as revealed by integral projection modelling. Functional Ecology, 32(10), 2407-2422. https://doi.org/10.1111/1365-2435.13192

CABI. (2020). Spodoptera littoralis (cotton leafworm). In: Invasive Species Compendium. Wallingford, UK: CAB International. http://www.cabi.org/isc/datasheet/51070 Caswell, H. (2001). In Matrix population models: Construction, analysis, and interpretation (2nd ed.). Sinauer Associates Inc.

Deutsch, C. A., Tewksbury, J. J., Huey, R. B., Sheldon, K. S., Ghalambor, C. K., Haak, D. C., \& Martin, P. R. (2008). Impacts of climate warming on terrestrial ectotherms across latitude. Proceedings of the National Academy of Sciences, 105(18), 6668-6672. https://doi.org/10.1073/pnas.0709472105

Deutsch, C. A., Tewksbury, J. J., Tigchelaar, M., Battisti, D. S., Merrill, S. C., Huey, R. B., \& Naylor, R. L. (2018). Increase in crop losses to insect pests in a warming climate. Science, 361(6405), 916-919. https://doi.org/10.1126/science.aat3466

Dillon, M. E., Wang, G., Garrity, P. A., \& Huey, R. B. (2009). Thermal preference in Drosophila. Journal of Thermal Biology, 34(3), 109-119. https://doi.org/10.1016/j.jtherbio.2008.11.007 
Dinh, K. V., Janssens, L., \& Stoks, R. (2016). Exposure to a heat wave under food limitation makes an agricultural insecticide lethal: A mechanistic laboratory experiment. Global Change Biology, 22(10), 3361-3372. https://doi.org/10.1111/gcb.13415

Ferrière, R., Sarrazin, F., Legendre, S., \& Baron, J.-P. (1996). Matrix population models applied to viability analysis and conservation: Theory and practice using the ULM software. Acta Oecologica, 17, 629-656.

Fournier-Level, A., Neumann-Mondlak, A., Good, R. T., Green, L. M., Schmidt, J. M., \& Robin, C. (2016). Behavioural response to combined insecticide and temperature stress in natural populations of Drosophila melanogaster. Journal of Evolutionary Biology, 29(5), 1030-1044. https://doi.org/10.1111/jeb.12844

Goulding, A. T., Shelley, L. K., Ross, P. S., \& Kennedy, C. J. (2013). Reduction in swimming performance in juvenile rainbow trout (Oncorhynchus mykiss) following sublethal exposure to pyrethroid insecticides. Comparative Biochemistry and Physiology Part C: Toxicology \& Pharmacology, 157(3), 280-286. https://doi.org/10.1016/j.cbpc.2013.01.001

Haug, G., \& Hoffman, G. (1990). Synthetic pyrethroid insecticides: Structures and properties. In Chemistry of Plant Protection (Vol. 4). Springer New York.

Hinks, C. F., \& Byers, J. R. (1976). Biosystematics of the genus Euxoa (Lepidoptera: Noctuidae): V. Rearing procedures, and life cycles of 36 species. The Canadian Entomologist, 108(12), 1345-1357. https://doi.org/10.4039/Ent1081345-12

Hooper, M. J., Ankley, G. T., Cristol, D. A., Maryoung, L. A., Noyes, P. D., \& Pinkerton, K. E. (2013). Interactions between chemical and climate stressors: A role for mechanistic toxicology in assessing climate change risks. Environmental Toxicology and Chemistry, 32(1), 32-48. https://doi.org/10.1002/etc.2043 
Johnson, L. R., Ben-Horin, T., Lafferty, K. D., McNally, A., Mordecai, E., Paaijmans, K. P., Pawar, S., \& Ryan, S. J. (2015). Understanding uncertainty in temperature effects on vector-borne disease: A Bayesian approach. Ecology, 96(1), 203-213. https://doi.org/10.1890/13-1964.1

Kehat, M., \& Gordon, D. (1975). Mating, longevity, fertility and fecundity of the cotton leafworm, Spodoptera littoralis (Boisd.) (Lepidoptera: Noctuidae). Phytoparasitica, 3(2), 87-102. https://doi.org/10.1007/BF03158291

Khafagi, W. E., Hegazi, E. M., \& Aamer, N. A. (2016). Effects of temperature on the development, food consumption and utilization parameters of the last two larval instars of Spodoptera littoralis (Boisd.). Journal of Agricultural Science and Food Technology, 2(6), 93-99.

Kingsolver, J. G. (2009). The well-temperatured biologist. The American Naturalist, 174(6), 755-768. https://doi.org/10.1086/648310

Kingsolver, J. G., Ragland, G. J., \& Shlichta, J. G. (2004). Quantitative genetics of continuous reaction norms: thermal sensitivity of caterpillar growth rates. Evolution 58(7), 1521-29. https://doi.org/10.1111/j.0014-3820.2004.tb01732.x

Lalouette, L., Pottier, M.-A., Wycke, M.-A., Boitard, C., Bozzolan, F., Maria, A., Demondion, E., Chertemps, T., Lucas, P., Renault, D., Maibeche, M., \& Siaussat, D. (2016). Unexpected effects of sublethal doses of insecticide on the peripheral olfactory response and sexual behavior in a pest insect. Environmental Science and Pollution Research, 23(4), 3073-3085. https://doi.org/10.1007/s11356-015-5923-3

Latzel, V. (2015). Pitfalls in ecological research: Transgenerational effects. Folia Geobotanica, 50(1), 75-85. https://doi.org/10.1007/s12224-015-9208-x 
Legendre, S., \& Clobert, J. (1995). ULM, a software for conservation and evolutionary biologists. Journal of Applied Statistics, 22(5-6), 817-834. https://doi.org/10.1080/02664769524649

Malbert-Colas, A., Drozdz, T., Massot, M., Bagni, T., Chertemps, T., Maria, A., Maïbèche, M., \& Siaussat, D. (2020). Effects of low concentrations of deltamethrin are dependent on developmental stages and sexes in the pest moth Spodoptera littoralis. Environmental Science and Pollution Research. https://doi.org/10.1007/s11356-020$10181-9$

Marshall, D. J., Heppell, S. S., Munch, S. B., \& Warner, R. R. (2010). The relationship between maternal phenotype and offspring quality: Do older mothers really produce the best offspring? Ecology, 91(10), 2862-2873. https://doi.org/10.1890/09-0156.1

Metcalf, C. J. E., \& Pavard, S. (2007). Why evolutionary biologists should be demographers. Trends in Ecology \& Evolution, 22(4), 205-212. https://doi.org/10.1016/j.tree.2006.12.001

Moe, S. J., De Schamphelaere, K., Clements, W. H., Sorensen, M. T., Van den Brink, P. J., \& Liess, M. (2013). Combined and interactive effects of global climate change and toxicants on populations and communities. Environmental Toxicology and Chemistry, 32(1), 49-61. https://doi.org/10.1002/etc.2045

Moore, M. P., Whiteman, H. H., \& Martin, R. A. (2019). A mother's legacy: The strength of maternal effects in animal populations. Ecology Letters, 22(10), 1620-1628. https://doi.org/10.1111/ele.13351

Mordecai, E. A., Caldwell, J. M., Grossman, M. K., Lippi, C. A., Johnson, L. R., Neira, M., Rohr, J. R., Ryan, S. J., Savage, V., Shocket, M. S., Sippy, R., Stewart Ibarra, A. M., Thomas, M. B., \& Villena, O. (2019). Thermal biology of mosquito-borne disease. Ecology Letters, 22(10), 1690-1708. https://doi.org/10.1111/ele.13335 
Mousseau, T. A., \& Dingle, H. (1991). Maternal effects in insect life histories. Annual Review of Entomology, 36(1), 511-534. https://doi.org/10.1146/annurev.en.36.010191.002455

Mousseau, T. A., \& Fox, W. (1998). The adaptive signifiance of maternal effects. Trends in Ecology and Evolution, 13(10), 403-407.

Mousseau, T. A., Uller, T., Wapstra, E., \& Badyaev, A. V. (2009). Evolution of maternal effects: Past and present. Philosophical Transactions of the Royal Society BBiological Sciences, 364(1520), 1035-1038.

Müller, C. (2018). Impacts of sublethal insecticide exposure on insects: Facts and knowledge gaps. Basic and Applied Ecology, 30, 1-10. https://doi.org/10.1016/j.baae.2018.05.001

Noyes, P. D., \& Lema, S. C. (2015). Forecasting the impacts of chemical pollution and climate change interactions on the health of wildlife. Current Zoology, 61(4), 669689. https://doi.org/10.1093/czoolo/61.4.669

Noyes, P. D., McElwee, M. K., Miller, H. D., Clark, B. W., Van Tiem, L. A., Walcott, K. C., Erwin, K. N., \& Levin, E. D. (2009). The toxicology of climate change: Environmental contaminants in a warming world. Environment International, 35(6), 971-986. https://doi.org/10.1016/j.envint.2009.02.006

Oppold, A., Kreß, A., Vanden Bussche, J., Diogo, J. B., Kuch, U., Oehlmann, J., Vandegehuchte, M. B., \& Müller, R. (2015). Epigenetic alterations and decreasing insecticide sensitivity of the Asian tiger mosquito Aedes albopictus. Ecotoxicology and Environmental Safety, 122, 45-53. https://doi.org/10.1016/j.ecoenv.2015.06.036

Orr, J. A., Vinebrooke, R. D., Jackson, M. C., Kroeker, K. J., Kordas, R. L., Mantyka-Pringle, C., Van den Brink, P. J., De Laender, F., Stoks, R., Holmstrup, M., Matthaei, C. D., Monk, W. A., Penk, M. R., Leuzinger, S., Schäfer, R. B., \& Piggott, J. J. (2020). Towards a unified study of multiple stressors: Divisions and common goals across 
research disciplines. Proceedings of the Royal Society B: Biological Sciences, 287(1926), 20200421. https://doi.org/10.1098/rspb.2020.0421

Riskallah, M. R. (1984). Influence of posttreatment temperature on the toxicity of pyrethroid insecticides to susceptible and resistant larvae of the Egyptian cotton leafworm, Spodoptera littoralis (Boisd.). Experientia, 40(2), 188-190.

https://doi.org/10.1007/BF01963592

Sidibé, B., \& Laugé, G. (1977). Incidence des thermopériodes et de températures constantes sur quelques critères biologiques de Spodoptera littoralis Boisduval [Lepidoptera Noctuidae]. Annales de La Société Entomologique de France, 13, 369-379.

Sinclair, B. J., Marshall, K. E., Sewell, M. A., Levesque, D. L., Willett, C. S., Slotsbo, S., Dong, Y., Harley, C. D. G., Marshall, D. J., Helmuth, B. S., \& Huey, R. B. (2016). Can we predict ectotherm responses to climate change using thermal performance curves and body temperatures? Ecology Letters, 19(11), 1372-1385. https://doi.org/10.1111/ele.12686

Tran, T. T., Janssens, L., Dinh, K. V., \& Stoks, R. (2018). Transgenerational interactions between pesticide exposure and warming in a vector mosquito. Evolutionary Applications, 11(6), 906-917. https://doi.org/10.1111/eva.12605

White, G. C., \& Burnham, K. P. (1999). Program MARK: survival estimation from populations of marked animals. Bird Study, 46, 120-139.

Whiten, S. R., \& Peterson, R. K. D. (2016). The influence of ambient temperature on the susceptibility of Aedes aegypti (Diptera: Culicidae) to the pyrethroid insecticide permethrin. Journal of Medical Entomology, 53(1), 139-143. https://doi.org/10.1093/jme/tjv159

WHO. (1989). Deltamethrin health and safety guide $N^{\circ} 30$. IPCS International Programme On Chemical Safety. World Health Organization, Geneva, ISBN 9241543515. 
Table 1. Reaction norms of the clutches reared at 23 and $25^{\circ} \mathrm{C}$ or at 27 and $29^{\circ} \mathrm{C}$. Table reports the interactions that tested the variation in the response of clutches to temperature and deltamethrin. The clutch factor $\left(\mathrm{C}_{\text {factor }}\right)$ considered for each parameter is the one selected in the best-fit models of Table S3. The Cfactor Clutch is the clutch identification numbers that tested total variation among clutches. Day and Week factors tested variation in the day or week of the collection of clutches, respectively.

C factor $\quad$ Temperature $\mathrm{x} \mathrm{C}_{\text {factor }} \quad$ Deltamethrin $\mathrm{x} \mathrm{C}_{\text {factor }}$

Temperatures of 23 and $25^{\circ} \mathrm{C}$

Larval survival Day $\quad X^{2}{ }_{8}=39.0 P<0.001 \quad X^{2}{ }_{10}=36.0 P<0.001$

Female developmental time Week $\quad X^{2}{ }_{3}=27.5 P<0.001 \quad X^{2}{ }_{4}=8.2 P=0.085$

Male developmental time Day $\quad X^{2}{ }_{8}=29.2 P<0.001 \quad X^{2}{ }_{10}=32.1 P<0.001$

Temperatures of 27 and $29^{\circ} \mathrm{C}$

Female developmental time

Day $\quad X^{2}{ }_{10}=76.1 P<0.001 \quad X^{2}{ }_{11}=15.2 P=0.174$

Male developmental time

Clutch $\quad X^{2}{ }_{10}=106.3 P<0.001 \quad X^{2}{ }_{13}=26.9 P=0.013$ 

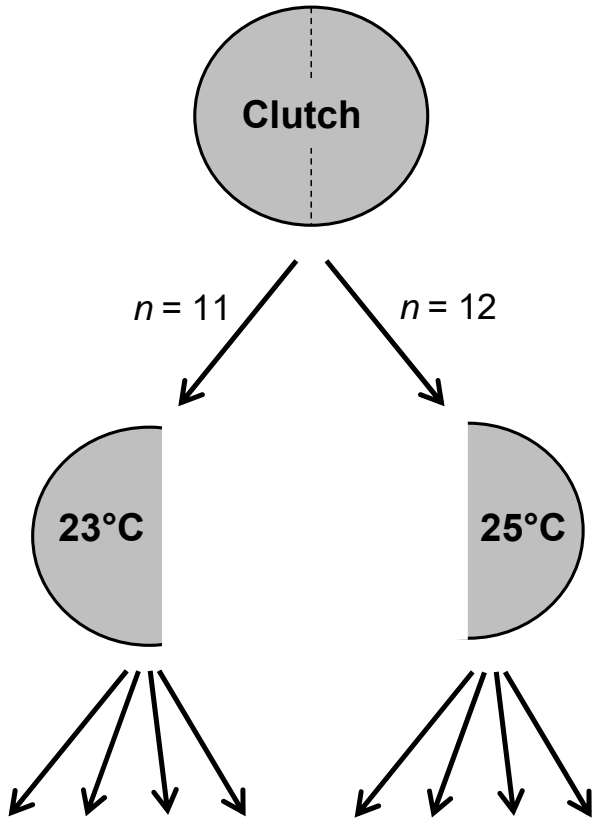

15 larvae per deltamethrin treatment

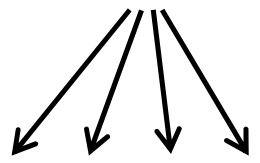

15 larvae per deltamethrin treatment
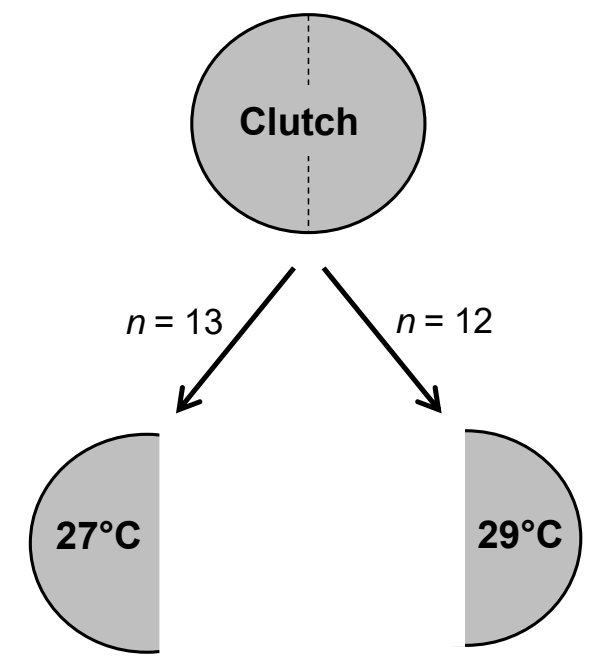

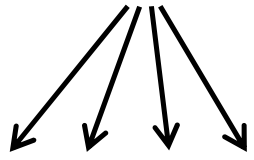

15 larvae per deltamethrin treatment

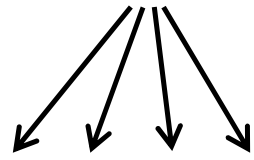

15 larvae per deltamethrin treatment

Fig. 1. Experimental design used to test the reaction norms of clutches to temperature and deltamethrin insecticide. Most clutches were divided into two parts to rear them under two different temperatures, and each of these half-clutches was divided into four groups where the deltamethrin treatments were applied ( 3 concentrations and 1 control solution). Overall, 2880 larvae were individually treated with insecticide solution at their $4^{\text {th }}$ instar. 


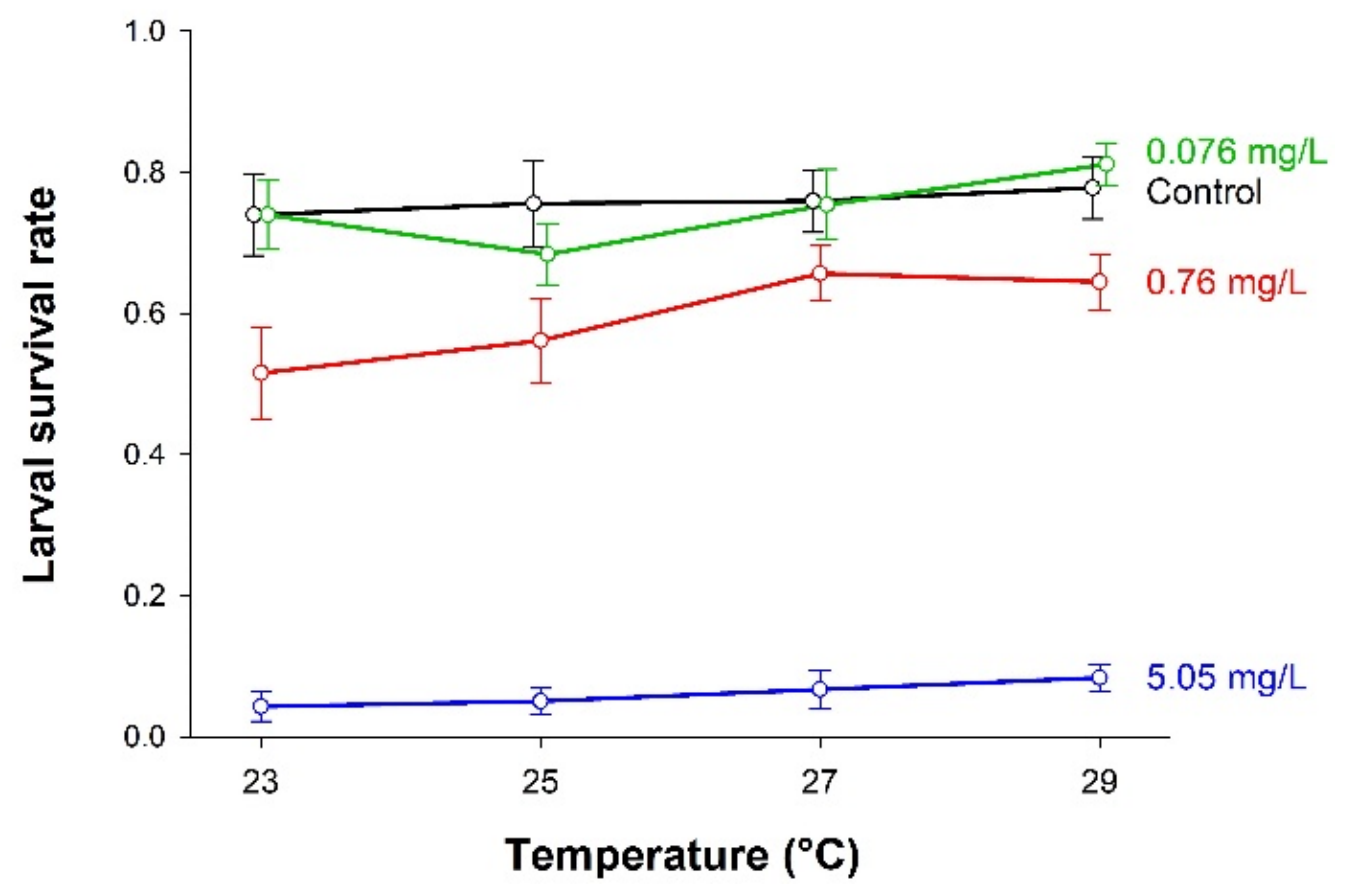

Fig. 2. Effects of temperature and deltamethrin on larval survival rates. Vertical lines represent the s.e.m. between clutches. 

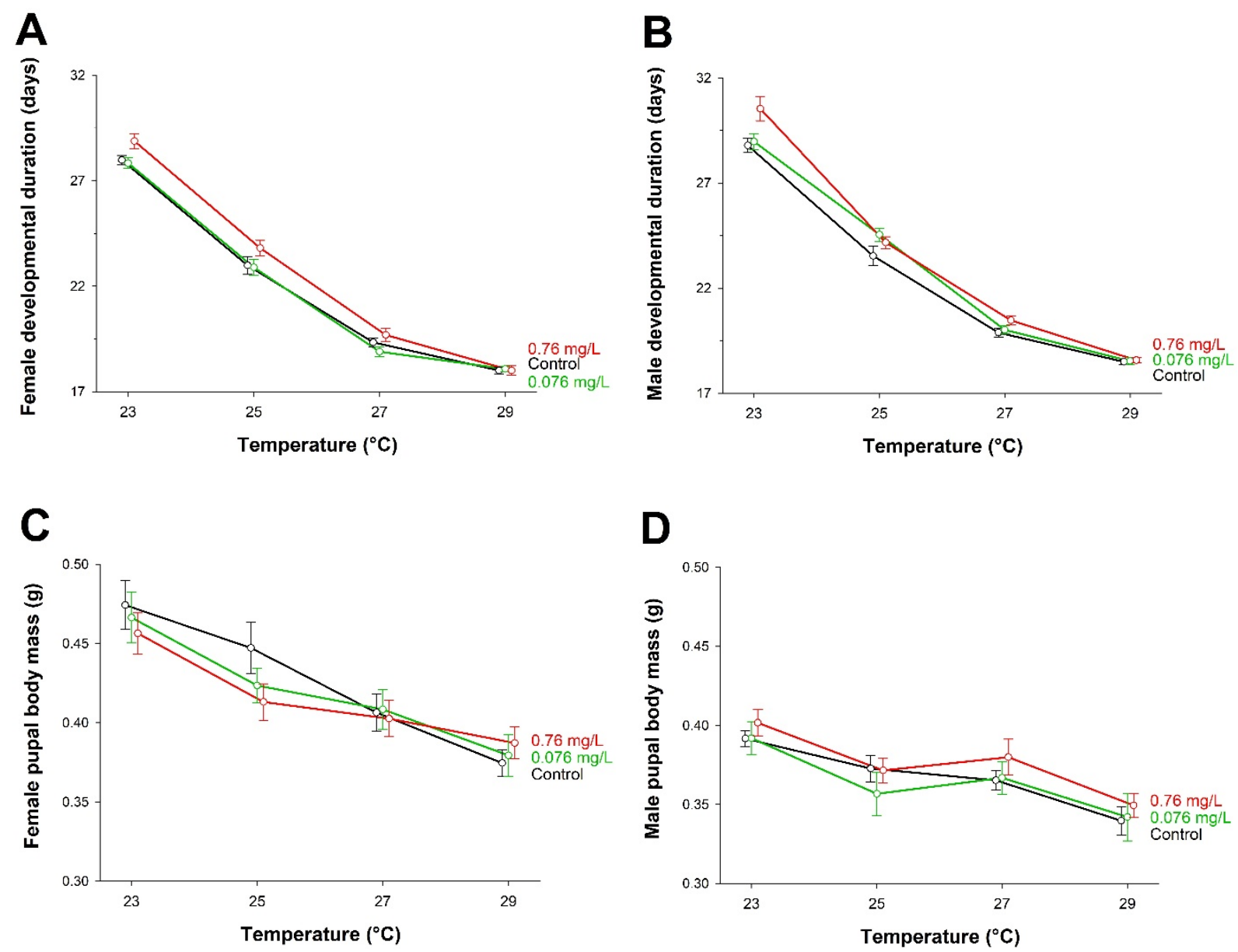

Fig. 3. Effects of temperature and deltamethrin on developmental time and body mass. A: time between the deltamethrin treatment $\left(4^{\text {th }}\right.$ larval instar $)$ and adult female emergence, B: time between the deltamethrin treatment and adult male emergence, $\mathbf{C}$ : female pupal body mass, $\mathbf{D}$ : male pupal body mass. Vertical lines represent the s.e.m. between clutches. 


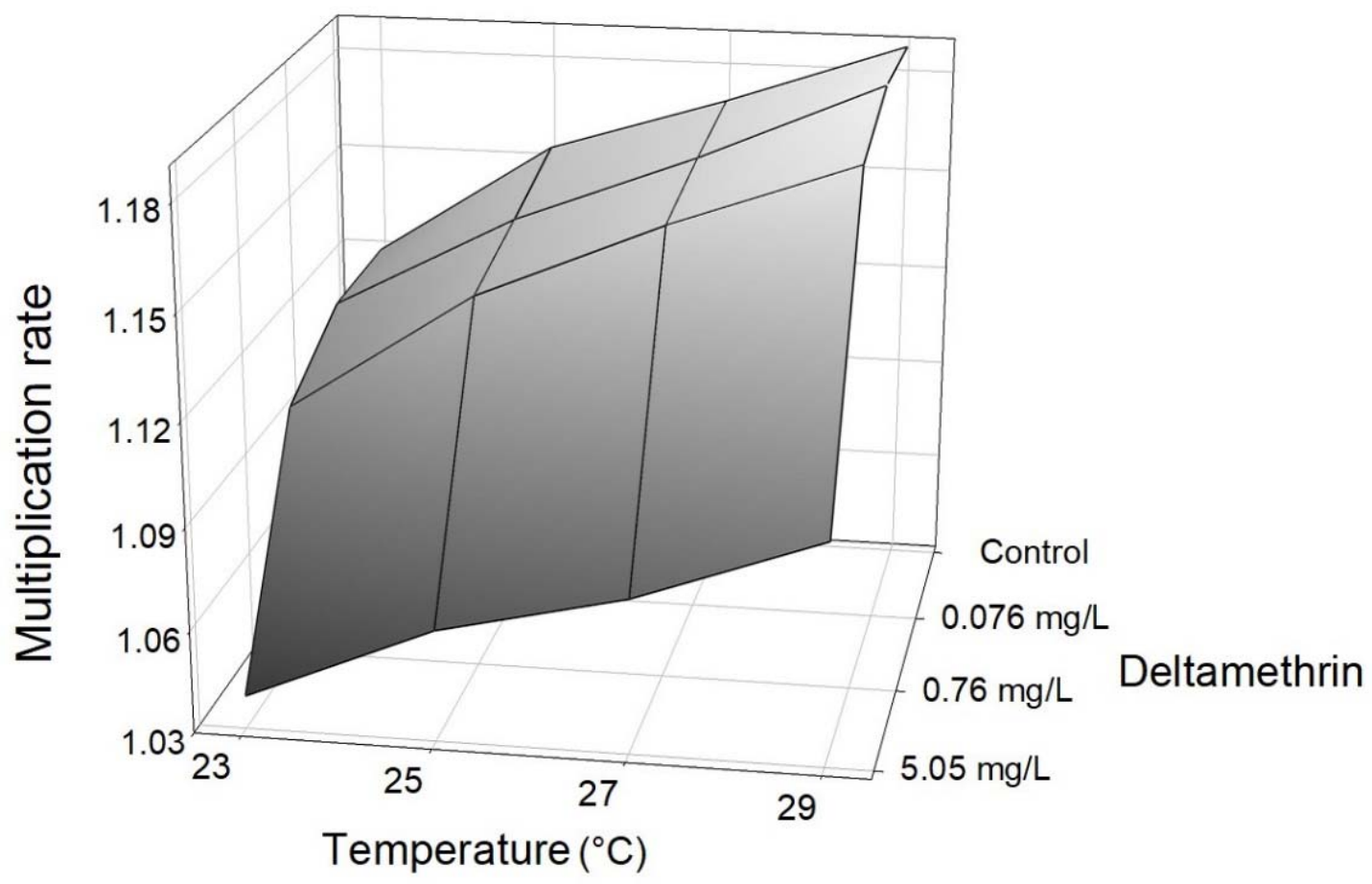

Fig. 4. Effects of developmental temperature and deltamethrin on the multiplication rate of simulated populations. 


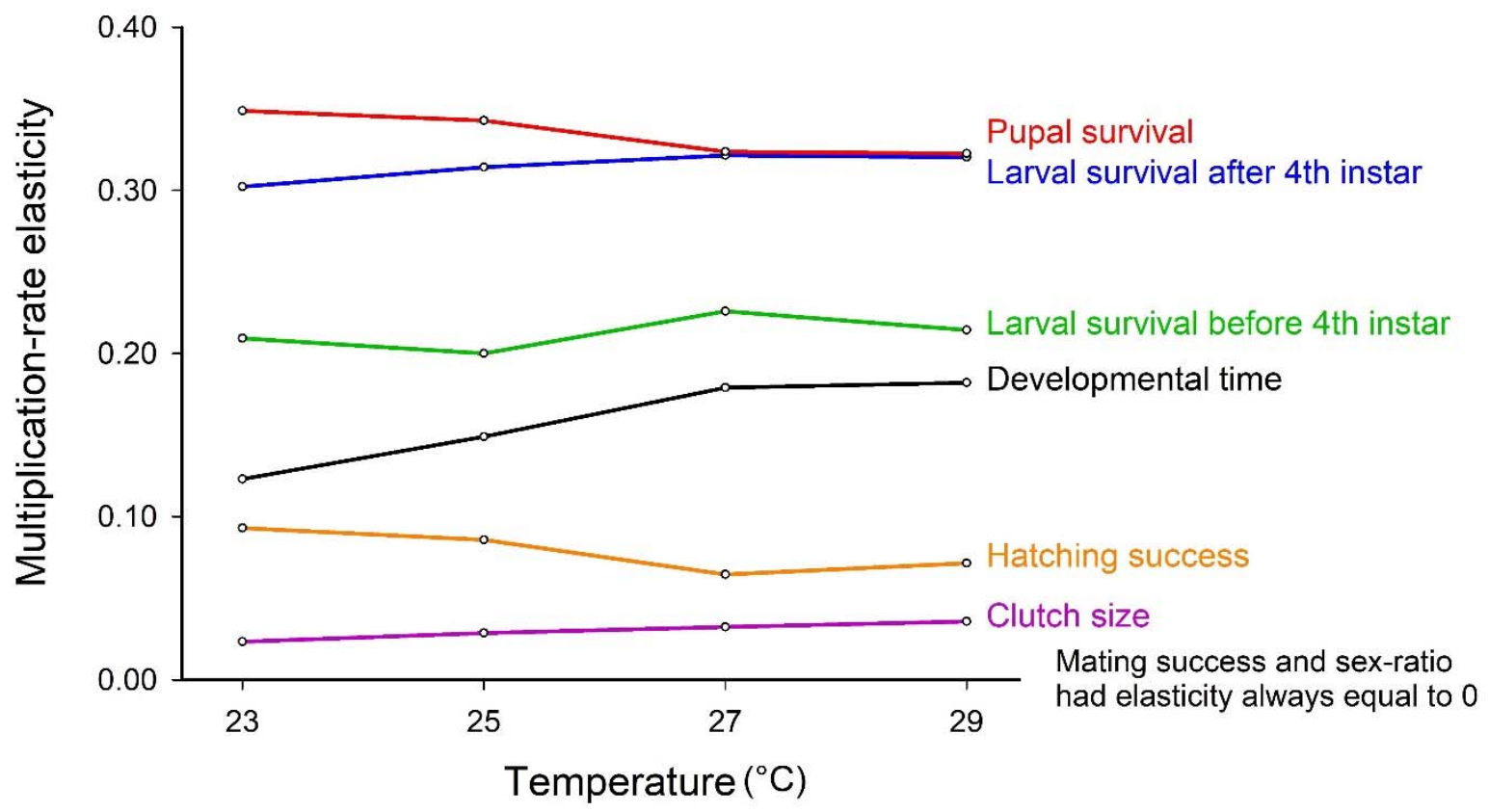

Fig. 5. Elasticity of the population multiplication-rate for the vital parameters of S. littoralis as a function of developmental temperature. Elasticities (i.e., relative sensitivities of the multiplication rate to the proportional change in the vital rates) were obtained from the models with the estimates obtained in the control groups without deltamethrin. 


\section{APPENDIXES for}

Figure S1 - Estimates of population multiplication-rate

Table S1 - Values used to fix parameters in matrix models

Table S2 - Sample sizes

Figure S2 - Pupal survival rates

Table S3 - Statistical modelling of variation among clutches 


\section{Figure S1: Estimates of population multiplication-rate}

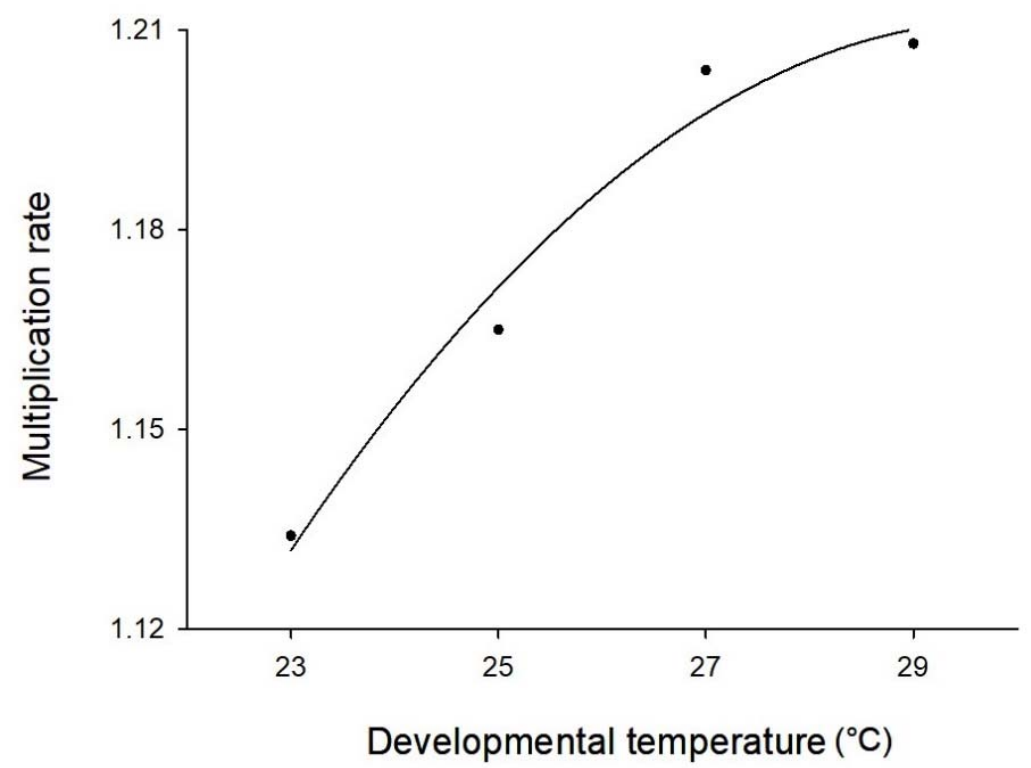

Figure S1. Population multiplication-rate of our strain of S. littoralis as a function of developmental temperature. Estimates were obtained from a preliminary study in spring 2017 . Four temperatures $\left(23,25,27\right.$ and $\left.29^{\circ} \mathrm{C}\right)$ were applied from eggs to adult emergence in an experiment without insecticide treatment. We measured early larval survival rate (between the $1^{\text {st }}$ and $4^{\text {th }}$ larval instars), late larval survival rate (between the $4^{\text {th }}$ larval instar and pupation), pupal survival rate, and developmental times (duration of incubation, between the $1^{\text {st }}$ and $4^{\text {th }}$ larval instars, between the $4^{\text {th }}$ larval instar and pupation, and between pupation and adult emergence). Based on these parameter estimates, we computed the population multiplication rate for each developmental temperature. We performed projection matrix models as described for our other matrix models (see Materials and Methods).

- Duration of incubation was estimated by the survey of 30 clutches divided into two parts, with 15 clutches reared at 23 or $25^{\circ} \mathrm{C}$ and 15 clutches reared at 27 or $29^{\circ} \mathrm{C}$.

- $\quad$ Early larval survival and developmental time between the $1^{\text {st }}$ and $4^{\text {th }}$ larval instars were estimated by the survey of experimental boxes with larvae from their $1^{\text {st }}$ instar (with an average of 58 larvae per box). We used a factorial design as in the main study (Fig. 1) to cross the factors temperature and clutch, resulting in 13 clutches for $23^{\circ} \mathrm{C}, 11$ for $25^{\circ} \mathrm{C}, 14$ for $27^{\circ} \mathrm{C}$, and 14 for $29^{\circ} \mathrm{C}$.

- $\quad$ Other parameters were estimated by the survey of experimental boxes of 40 larvae from their $4^{\text {th }}$ instar. At the beginning of the survey, the number of clutches per temperature was of 14 for $23^{\circ} \mathrm{C}, 14$ for $25^{\circ} \mathrm{C}, 15$ for $27^{\circ} \mathrm{C}$, and 15 for $29^{\circ} \mathrm{C}$. 


\section{Table S1: Values used to fix parameters in matrix models}

Table S1a. Estimates of the parameters used in matrix models for the control groups without deltamethrin. For the parameter indicated with *, we used estimates obtained from the preliminary study of 2017 with the four developmental temperatures. For the reproductive parameters indicated with ${ }^{* *}$, we used estimates obtained from another study (Malbert-Colas et al., 2020) from a control group of adults reared at $23^{\circ} \mathrm{C}$ (however, Fig. 5 of the present study shows that the influence of reproductive parameters on the multiplication rate of $S$. littoralis is much smaller than the influence of the parameters we estimated under the 4 developmental temperatures).

\begin{tabular}{|c|c|c|c|c|c|}
\hline Developmental temperature & & $23^{\circ} \mathrm{C}$ & $25^{\circ} \mathrm{C}$ & $27^{\circ} \mathrm{C}$ & $29^{\circ} \mathrm{C}$ \\
\hline Duration of incubation period (days) & $*$ & 4 & 3 & 2 & 2 \\
\hline Duration $1^{\text {st }}-4^{\text {th }}$ instars (days) & $*$ & 9 & 7 & 7 & 6 \\
\hline Duration $4^{\text {th }}$ instar - pupation (days) & & 13 & 11 & 10 & 9 \\
\hline Duration of pupal period (days) & & 15 & 12 & 10 & 9 \\
\hline Survival from $1^{\text {st }}$ to $4^{\text {th }}$ instars (\%) & $*$ & 68.0 & 81.1 & 68.2 & 63.9 \\
\hline Survival from $4^{\text {th }}$ instar to pupation (\%) & & 73.9 & 75.6 & 75.9 & 77.8 \\
\hline Pupal survival (\%) & & 95.0 & 92.0 & 95.9 & 96.4 \\
\hline Sex-ratio (\% of females) & & 45.9 & 29.7 & 46.6 & 40.7 \\
\hline Adult female survival until laying (\%) & $* *$ & 92.8 & 92.8 & 92.8 & 92.8 \\
\hline Laying success after mating (\%) & $* *$ & 78.3 & 78.3 & 78.3 & 78.3 \\
\hline Number of eggs laid & $* *$ & 371 & 371 & 371 & 371 \\
\hline Hatching success (\%) & ** & 71.3 & 71.3 & 71.3 & 71.3 \\
\hline
\end{tabular}


Table S1b. Estimates of the parameters used in matrix models with $0.076 \mathrm{mg} / \mathrm{L}$ of deltamethrin. The values for other parameters are reported in Table S2A.

\begin{tabular}{rcccc} 
Developmental temperature & $23^{\circ} \mathrm{C}$ & $25^{\circ} \mathrm{C}$ & $27^{\circ} \mathrm{C}$ & $29^{\circ} \mathrm{C}$ \\
\hline Duration 4 ${ }^{\text {th }}$ instar - pupation (days) & 13 & 12 & 10 & 9 \\
Duration of pupal period (days) & 15 & 12 & 10 & 9 \\
Survival from 4 ${ }^{\text {th }}$ instar to pupation (\%) & 73.9 & 68.3 & 75.4 & 81.1 \\
Pupal survival (\%) & 93.4 & 94.3 & 89.1 & 94.5 \\
Sex-ratio (\% of females) & 37.8 & 53.7 & 42.9 & 39.0 \\
\hline
\end{tabular}

Table S1c. Estimates of the parameters used in matrix models with $0.76 \mathrm{mg} / \mathrm{L}$ of deltamethrin. The values for other parameters are reported in Table S2A.

\begin{tabular}{rcccc} 
Developmental temperature & $23^{\circ} \mathrm{C}$ & $25^{\circ} \mathrm{C}$ & $27^{\circ} \mathrm{C}$ & $29^{\circ} \mathrm{C}$ \\
\hline Duration 4 ${ }^{\text {th }}$ instar - pupation (days) & 14 & 12 & 10 & 9 \\
Duration of pupal period (days) & 16 & 12 & 10 & 9 \\
Survival from 4 ${ }^{\text {th }}$ instar to pupation (\%) & 51.6 & 56.1 & 65.6 & 64.4 \\
Pupal survival (\%) & 96.4 & 94.1 & 91.3 & 95.7 \\
Sex-ratio (\% of females) & 52.9 & 44.6 & 50.8 & 46.1 \\
\hline
\end{tabular}

Table S1d. Estimates of the parameters used in matrix models with $5.05 \mathrm{mg} / \mathrm{L}$ of deltamethrin. The values for other parameters are reported in Table S2A.

\begin{tabular}{rcccc} 
Developmental temperature & $23^{\circ} \mathrm{C}$ & $25^{\circ} \mathrm{C}$ & $27^{\circ} \mathrm{C}$ & $29^{\circ} \mathrm{C}$ \\
\hline Duration 4 ${ }^{\text {th }}$ instar - pupation (days) & 15 & 12 & 11 & 10 \\
Duration of pupal period (days) & 17 & 13 & 11 & 9 \\
Survival from 4 $4^{\text {th }}$ instar to pupation (\%) & 4.2 & 5.0 & 6.7 & 8.3 \\
Pupal survival (\%) & 83.3 & 88.9 & 91.7 & 100.0 \\
Sex-ratio (\% of females) & 42.9 & 44.4 & 66.7 & 46.7 \\
\hline
\end{tabular}




\section{Table S2: Sample sizes}

Table S2a. Sample sizes per temperature for the control groups without deltamethrin

\begin{tabular}{|c|c|c|c|c|}
\hline & $23^{\circ} \mathrm{C}$ & $25^{\circ} \mathrm{C}$ & $27^{\circ} \mathrm{C}$ & $29^{\circ} \mathrm{C}$ \\
\hline Larval survival & 165 & 180 & 195 & 180 \\
\hline Female pupal survival & 55 & 54 & 69 & 57 \\
\hline Male pupal survival & 66 & 82 & 79 & 83 \\
\hline Female developmental time & 53 & 51 & 66 & 54 \\
\hline Male developmental time & 62 & 75 & 76 & 81 \\
\hline Female pupal body mass & 22 & 22 & 26 & 24 \\
\hline Male pupal body mass & 22 & 24 & 26 & 24 \\
\hline
\end{tabular}

Table S2b. Sample sizes per temperature for the groups with $0.076 \mathrm{mg} / \mathrm{L}$ of deltamethrin

\begin{tabular}{|c|c|c|c|c|}
\hline & $23^{\circ} \mathrm{C}$ & $25^{\circ} \mathrm{C}$ & $27^{\circ} \mathrm{C}$ & $29^{\circ} \mathrm{C}$ \\
\hline Larval survival & 165 & 180 & 195 & 180 \\
\hline Female pupal survival & 45 & 66 & 63 & 57 \\
\hline Male pupal survival & 79 & 56 & 84 & 88 \\
\hline Female developmental time & 42 & 63 & 57 & 53 \\
\hline Male developmental time & 71 & 53 & 74 & 85 \\
\hline Female pupal body mass & 22 & 23 & 24 & 24 \\
\hline Male pupal body mass & 22 & 24 & 26 & 24 \\
\hline
\end{tabular}

Table S2c. Sample sizes per temperature for the groups with $0.76 \mathrm{mg} / \mathrm{L}$ of deltamethrin

\begin{tabular}{|c|c|c|c|c|}
\hline & $23^{\circ} \mathrm{C}$ & $25^{\circ} \mathrm{C}$ & $27^{\circ} \mathrm{C}$ & $29^{\circ} \mathrm{C}$ \\
\hline Larval survival & 165 & 180 & 195 & 180 \\
\hline Female pupal survival & 44 & 45 & 63 & 53 \\
\hline Male pupal survival & 40 & 56 & 63 & 62 \\
\hline Female developmental time & 41 & 42 & 57 & 52 \\
\hline Male developmental time & 39 & 53 & 58 & 58 \\
\hline Female pupal body mass & 20 & 22 & 21 & 24 \\
\hline Male pupal body mass & 20 & 23 & 24 & 24 \\
\hline
\end{tabular}


Table S2d. Sample sizes per temperature for the groups with $5.05 \mathrm{mg} / \mathrm{L}$ of deltamethrin

\begin{tabular}{|c|c|c|c|c|}
\hline & $23^{\circ} \mathrm{C}$ & $25^{\circ} \mathrm{C}$ & $27^{\circ} \mathrm{C}$ & $29^{\circ} \mathrm{C}$ \\
\hline Larval survival & 165 & 180 & 195 & 180 \\
\hline Female pupal survival & 3 & 4 & 8 & 7 \\
\hline Male pupal survival & 3 & 5 & 4 & 8 \\
\hline Female developmental time & 3 & 4 & 7 & 7 \\
\hline Male developmental time & 2 & 4 & 4 & 8 \\
\hline Female pupal body mass & 3 & 4 & 6 & 7 \\
\hline Male pupal body mass & 4 & 5 & 3 & 7 \\
\hline
\end{tabular}




\section{Figure S2: Pupal survival rates}
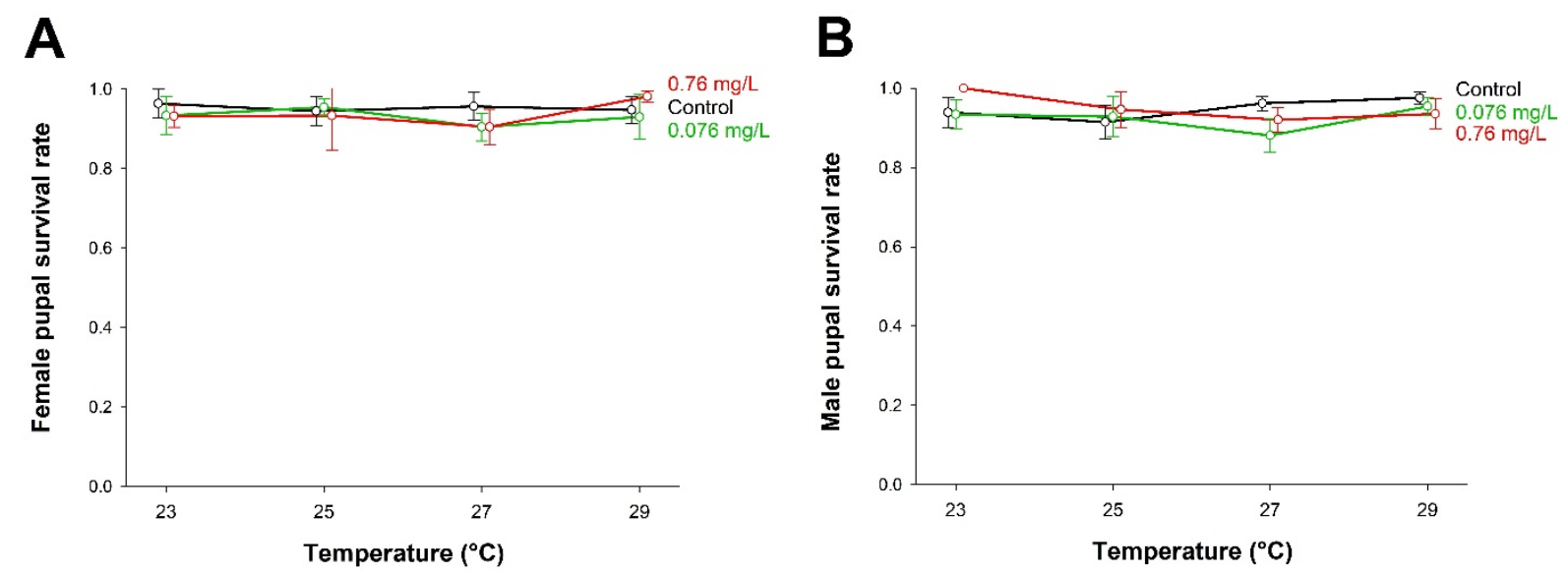

Figure S2. Effects of temperature and deltamethrin on pupal survival rates. A: female pupal survival, and B: male pupal survival. Vertical lines represent the s.e.m. between clutches. 


\section{Table S3: Statistical modelling of variation among clutches}

Table S3. Tests of the variation among clutches reared at 23 and $25^{\circ} \mathrm{C}$ or at 27 and $29^{\circ} \mathrm{C}$. Statistical modelling was performed with no clutch variation (Mo models), total variation among clutches (Clutch), and variation in the day or week of the collection of clutches (Day, Week). All models included temperature, deltamethrin treatments, Temperature x Deltamethrin interaction, and all interactions with the clutch factor tested. The table reports AICc, i.e., Akaike Information Criterion corrected for small sample size (White \& Burnham, 1999). The lower the AICc value is, the more appropriate the model is to fit the data. The best fitted models with the lowest AICc values are reported in bold. Logistic analyses were used for all parameters, except for pupal body mass analysed with generalized linear models.

\begin{tabular}{rrrrr} 
& Mo & Clutch & Day & Week \\
\hline Temperatures of 23 and 25 ${ }^{\circ} \mathrm{C}$ & & & & \\
Larval survival & 873.0 & 839.3 & 833.2 & 854.9 \\
Memale pupal survival & 92.5 & 187.6 & 162.2 & 107.7 \\
Memale pupal survival & 109.6 & 190.8 & 169.3 & 132.3 \\
Male developmental time & 237.4 & 242.1 & 226.4 & 205.0 \\
Female pupal body mass & 296.9 & 250.7 & 245.4 & 279.0 \\
Male pupal body mass & -236.1 & -201.4 & -203.4 & -204.1 \\
Temperatures of 27 and 29 ${ }^{\circ} \mathrm{C}$ & -338.8 & -294.0 & -297.6 & -300.3 \\
Larval survival & & & & \\
Female pupal survival & 899.4 & 931.7 & 915.3 & 901.9 \\
Male pupal survival & 105.9 & 206.6 & 183.0 & 129.0 \\
Female developmental time & 117.1 & 209.2 & 186.4 & 133.2 \\
Male developmental time & 308.1 & 301.2 & 291.5 & 307.4 \\
Female pupal body mass & 348.9 & 283.5 & 287.9 & 313.2 \\
Male pupal body mass & -317.5 & -287.2 & -291.5 & -284.4 \\
\hline & -336.4 & -292.4 & -293.2 & -292.6 \\
\hline
\end{tabular}

